\title{
Faktor Faktor yang Mempengaruhi Investasi Asing Langsung pada Sektor Perkebunan di Indonesia
}

\author{
RIZKY P. LUBIS, MUHAMMAD FIRDAUS, HENDRO SASONGKO
}

Program Pascasarjana Manajemen dan Bisnis, Institut Pertanian Bogor, Bogor, Indonesia Email Korespondensi: 1bsriszky@gmail.com, firdausfemipb@yahoo.com

\begin{abstract}
Abstrak
Realisasi investasi di Indonesia didominasi oleh investor asing di mana sektor padat modal seperti industri pertambangan adalah fokus utama. Untuk memperkuat peran mereka dalam ekonomi nasional, investor asing harus diarahkan ke sektor perkebunan karena memiliki peran besar dalam penyerapan tenaga kerja dan neraca perdagangan yang positif. Menurut MP3EI, realisasi investasi di sektor perkebunan telah mencapai 2,29 persen Maret 2013 yang masih di bawah target. Penelitian ini bertujuan untuk menganalisis faktor-faktor penentu investasi dilakukan analisis vektor error correction model asing langsung dan strategi dirumuskan dengan menggunakan matriks SWOT untuk meningkatkan sektor perkebunan Indonesia. Variabel yang digunakan dalam model ini adalah investasi langsung asing, nilai ekspor, nilai tukar, suku bunga domestik, suku bunga di Amerika Serikat Negara, indeks harga konsumen, produk domestik bruto dan krisis sebagai variabel dummy. Alternatif strategi dirumuskan model SWOT didasarkan pada kuesioner dan wawancara responden dirancang dalam rangka proses hirarki analisis. Hasil dari model yang menyarankan bahwa nilai tukar jangka pendek, nilai ekspor, suku bunga Amerika Serikat, produk domestik bruto dan indeks harga konsumen memiliki dampak positif terhadap investasi asing langsung. Pada krisis sisi lain memiliki dampak negatif. Sementara itu di jangka panjang, suku bunga domestik, indeks produk domestik bruto dan harga konsumen memiliki dampak positif tetapi krisis memiliki kontribusi negatif. Prioritas strategi untuk meningkatkan investasi asing langsung di sektor perkebunan Indoensia dapat dilakukan melalui harmonisasi antara peraturan pemerintah pusat dan daerah.
\end{abstract}

Kata kunci: Investasi Asing Langsung, Vector Error Correction Model, SWOT Matriks

\section{Determinant of Foreign Direct Investment in Indonesia Plantation Sector}

\begin{abstract}
Realization of investment in Indonesia is dominated by foreign investors where capital intensive sector such as mining industry is the primary focus. To strengthen their roles in national economies, foreign investors should be directed to plantation sector since it has huge role in labor absorption and positive trade balance. According to MP3El, realization of investment in plantation sector has reached 2.29 percent in march 2013 which was still below of target. This research aimed to analyze determinants of foreign direct investment conducted vector error correction model analysis and formulated strategies by using SWOT matrix to increase Indonesia plantation sector. Variables used in this model were foreign direct investment, exports value, exchange rates, domestic interest rates, interest rates in United State of America, consumer price index, gross domestic product and crisis as dummy variable. The strategy alternatives were formulated by SWOT model based on the questionnaire and respondents interview designed in analytical hierarchy process framework. The result from model suggested that in the short term exchange rate, value of exports, United States interest rates, gross domestic product and consumer price index had positive impact to foreign direct investment. On the other side crisis had negative impact. Meanwhile in long term, domestic interest rates, gross domestic product and consumer price index had positive impact but crisis had negative contribution. The strategy priority to increase foreign direct investment in Indoensia plantation sector can be undertaken through harmonization between central and local governments regulations.
\end{abstract}

Keywords: Foreign Direct Investment, Vector Error Correction Model, SWOT Matrix 


\section{PENDAHULUAN}

\section{Latar Belakang}

Peraturan Presiden No 32 Tahun 2011 tentang Masterplan Percepatan dan Perluasan Pembangunan Ekonomi Indonesia (MP3EI) merupakan sebuah langkah besar permerintah dalam mencapai visi Indonesia Mandiri, Maju, Adil dan Makmur yang menjadi arah pembangunan ekonomi Indonesia hingga tahun 2025. MP3EI merupakan sebuah konsep yang komprehensif dalam dengan memadukan berbagai potensi wilayah Indonesia dengan berbagai dinamika. Latar belakang dari Perpres tersebut tersirat kekhawatiran bahwa tantangan pembangunan ekonomi Indonesia tidak mudah diselesaikan karena mengharuskan untuk senantiasa siap terhadap perubahan. Untuk melaksanakan langkah tersebut diperlukan investasi senilai Rp 4.012 Triliun, dimana Pemerintah hanya akan berkontribusi sebesar 10 persen dan BUMN sebesar 18 persen. Sementara kontribusi investasi pihak swasta sebesar 51 persen, sedangkan sisanya sebesar 21 persen akan dilaksanakan secara bauran antara pemerintah, BUMN dan swasta.

Realisasi investasi di Indonesia saat ini didominasi oleh penanam modal asing dengan fokus investasi pada sektor pertambangan yang merupakan sektor padat modal. Kontribusi sektor pertambangan terhadap penyerapan tenaga kerja terbilang rendah hanya sebesar 1.44 persen, dibandingkan penyerapan tenaga kerja di sektor perkebunan. Sektor perkebunan merupakan sektor yang memiliki penyerapan tenaga kerja terbesar dibandingkan dengan seluruh sektor lainnya dengan kontribusi sebesar 19.06 persen. Sektor perkebunan juga sebagai penyumbang devisa terbesar di sektor pertanian karena memiliki surplus neraca perdagangan yang besar. Oleh karena itu, pemerintah seharusnya mengarahkan investasi asing langsung terhadap sektor perkebunan. Indonesia merupakan eksportir terbesar minyak sawit dunia, produsen kakao dan karet terbesar ke-2 dunia, dengan faktor input seperti luas lahan, buruh yang terampil dan tersedia dalam jumlah yang cukup serta kebutuhan dunia akan bahan pokok hasil perkebunan yang bervariatif seperti minyak sawit, karet, dan coklat sangat potensial untuk ditanam di Indonesia sehingga merupakan pull factor investasi asing di sektor perkebunan. Berdasarkan laporan
MP3El (Masterplan Percepatan dan Perluasasan Pembangunan Ekonomi Indonesia), capaian realisasi investasi di sektor perkebunan hanya sebesar 2.29 persen dibandingkan dengan target yang ditetapkan.

\section{Tujuan}

Berdasarkan latar belakang yang telah diuraikan di atas maka tujuan dari penelitian ini adalah (1) Menganalisis faktor-faktor yang mempengaruhi investasi asing langsung sektor perkebunan di Indonesia dan (2) Merumuskan strategi untuk meningkatkan investasi asing langsung di sektor perkebunan di Indonesia.

\section{Kerangka Teori}

\section{Investasi Asing Langsung}

Menurut Undang Undang No 25 Tahun 2007 tentang Penanaman Modal Pasal (1) butir (3) penanaman modal asing adalah kegiatan menanam modal untuk melakukan usaha di wilayah negara Republik Indonesia yang dilakukan oleh penanaman modal asing baik yang menggunakan modal asing sepenuhnya maupun yang berpatungan dalam negeri. Penanaman modal asing ini wajib dalam bentuk perseroan terbatas dan dilakukan dengan cara mengambil bagian saham pada saat pendirian perseroan terbatas, membeli saham.

\section{Faktor yang mempengaruhi Investasi Asing Langsung} Menurut Yati, (2007), secara konseptual, pilihan investor asing untuk menanamkan investasinya dalam bentuk investasi asing langsung, dibanding bentuk modal lainnya di suatu negara, dipengaruhi oleh kondisi dari negara penerima investasi asing langsung (pull factors) maupun kondisi dan strategi dari penanam modal asing (push factors).

Pull factor merupakan kebijakan pemerintah yang menguntungkan investor yang mempengaruhi gelombang penanaman modal asing di suatu negara. Salah satu faktor penarik investor di Indonesia yakni meningkatnya tingkat daya beli domestik masyarakat Indonesia. Push factor merupakan faktor pendorong MNC (multinational company) untuk memindahkan lokasi operasinya ke luar negeri adalah meningkatnya biaya biaya lahan, upah tenaga kerja di home country yang membuat banyak kegiatan usaha yang turun daya saingnya sehingga menurunkan tingkat return investor, sementara di host country miskin modal dan memiliki tingkat upah buruh yang rendah sehingga kombinasi ini yang melatarbelakangi dilakukannya 
pengembangan produksi lintas negara. Salah satu faktor yang mendorong Jepang melakukan investasi di Indonesia yakni menguatnya nilai tukar mata uang yen yang mengakibatkan biaya produksi di negeri sakura menjadi mahal, disampig itu Indonesia merupakan negara ranking lima investment destination orang Jepang (Chatib, 2012).

\section{Lingkungan Internal dan Eksternal}

Menurut Wheelen dan Hunger (2012), analisa lingkungan internal adalah analisa yang dilakukan pada level internal organisasi/industri dalam rangka menilai kekuatan dan kelemahan yang dimiliki oleh organisasi. Adapun yang tercakup dalam lingkungan internal adalah faktor sumber daya, strategi yang digunakan dan faktor kinerjanya. Sedangkan analisa lingkungan eksternal adalah faktor-faktor yang mengekpresikan diri sebagai peluang dan ancaman dari organisasi/industry yang memiliki kemampuan untuk mempengaruhi suatu organisasi secara paksa dan pada akhirnya memberikan dampak pengaruh timbal balik antara organisasi dan lingkungan tersebut (Tina, 2010). Adapun faktor-faktor yang tercakup dalam faktor eksternal tersebut yakni politik, ekonomi, sosial, teknologi, lingkungan dan hukum.

\section{Identifikasi Isu Strategis}

Menurut Hari (2004), untuk memilih dan menyeleksi isu strategis, maka dapat digunakan beberapa teknik analisa isu strategis yakni (1) Matriks internal dan eksternal, yang dilakukan dengan analisis dan evaluasi untuk mengetahui kelemahan dan kekuatan serta mengkaji peluang dan ancaman yang dihadapi dalam suatu organisasi/industri. (2) Matriks profil kompetitif, yang dilakukan dengan mengidentifikasi faktor kelemahan dan kekuatan organisasi/industri yang sejenis agar dapat diadaptasi atau digunakan strateginya. (3) Matriks memperkuat dan mengevaluasi posisi (SPACE), yang dilakukan dengan mencocokan kemampuan sumber daya internal untuk memperkuat posisi dengan peluang yang ada serta mengatasi atau menghindari risiko faktor eksternal. (4) Matriks boston consulting group, dilakukan dengan menetapkan strategi yang berbeda untuk setiap unit bisnis/anak usaha dalam suatu perusahaan. (5) Matriks Grand Strategy yang dilakukan dengan menetapkan posisi yang kompetitif diukur dari tingkat keunggulan atau keberhasilan maksimum yang dapat dicapai.
Untuk penelitian ini akan digunakan teknik matriks internal dan eksternal untuk memperoleh isu strategis dan kombinasi strategi dari hasil silangan matriks bagi peningkatan investasi asing langsung pada sektor perkebunan di Indonesia. Semua narasi dari analisa ini akan dimuarakan pada analisa matriks SWOT untuk melihat strategi baru yang tepat dan handal.

\section{Strategi Prioritas}

Strategiyang telah diformulasikan berdasarkan analisis SWOT kemudian dipilih berdasarkan dari analisa scaleup (biaya dan dampak dari strategi). Proses ini akan melibatkan banyak pemikiran mengenai bagaimana menentukan strategi prioritas. Maka diperlukan strategi prioritas yang dapat membantu menentukan strategi yang akan diutamakan dengan beberapa pertimbangan (1) Manfaat dalam pelaksanaan; (2) Keterbatasan finansial, (3) keterbatasan sumber daya manusia yang akan melakukan implementasi strategi tersebut, serta (4) Keterbatasan waktu pelaksanaan apabila strategi dilakukan sekaligus.

\section{KAJIAN LITERATUR}

Penelitian yang dilakukan oleh Yati et al (2007), Yutaka (2012), Afrizawati (2011) dan Sarwedi (2002) terkait dengan faktor faktor yang mendorong masuknya investasi asing langsung ke suatu negara adalah pertumbuhan ekonomi, upah buruh, infrastruktur, nilai tukar relatif serta meningkatkan pendapatan negara penerima investasi asing langsung dan selanjutnya akan membawa pertumbuhan ekonomi negara tersebut.

Untuk menarik investasi asing perlu dilakukan penjelasan terkait dengan potensi daerah baik melalui letak posisi yang strategis, tenaga kerja yang berkeahlian serta infrastruktur yang memadai. Hal ini dapat diimplementasikan melalui startegi diferensiasi dan optimalisasi strategy marketing mix (Tina, 2010).

Dari beberapa literature review maka dapat dibuat suatu hipotesa awal tentang faktor-faktor yang mempengaruhi investasi asing langsung di bidang perkebunan di Indonesia. (1) Nilai ekspor berpengaruh positif pada pembentukan investasi asing langsung. (2) Gross Domestic Product berpengaruh positif pada pembentukan investasi asing langsung. (3) Depresiasi nilai tukar rupiah terhadap dolar Amerika 


\section{JURNAL BISNIS \& MANAJEMEN}

ISSN 1412 - 3681

Serikat berpengaruh negatif terhadap investasi asing langsung. (4) Tingkat suku bunga dalam negeri berpengaruh negatif terhadap investasi asing langsung. (5) Suku bunga luar negeri berpengaruh negatif terhadap investasi asing langsung. (6) Tingkat indeks harga konsumen berpengaruh positif terhadap investasi asing langsung.

\section{Kerangka Pemikiran Konseptual}

Perumusan masalah dalam penelitian ini adalah rendahnya realisasi investasi asing langsung di sektor perkebunan dalam program MP3EI. Realisasi investasi tersebut hanya sebesar 2.35 persen dibandingkan dengan target yag telah ditetapkan. Untuk menjawab rumusan masalah tersebut maka dilakukan analisis terhadap faktor-faktor yang mempengaruhi investasi asing langsung pada sektor perkebunan di Indonesia serta merumuskan strategi untuk meningkatkan investasi asing langsung pada sektor perkebunan di Indonesia. Adapun tahapan dalam penelitian ini adalah 1) menggunakan model ekonometrika metode Vector Autoregression (VAR) atau Vector Error Correction Model (VECM) dengan menggunakan data time series tahunan; 2) mengevaluasi faktor eksternal dan internal yang mempengaruhi investasi asing langsung pada sektor perkebunan di Indonesia, kemudian menentukan alternatif strategi yang dirumuskan melalui matriks SWOT serta menentukan prioritas strategi untuk meningkatkan investasi asing langsung tersebut.

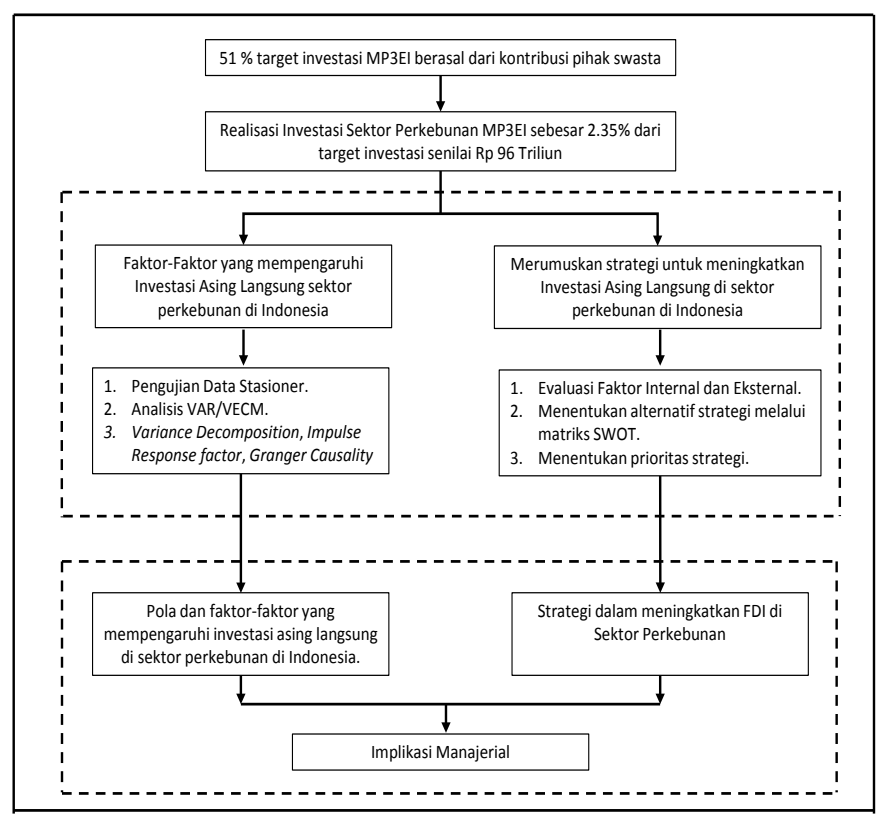

Gambar 1 Kerangka Pemikiran Konseptual
Jurnal Bisnis \& Manajemen, 2015, Vol. XVI, No. 2, 80-89

\section{METODE}

Analisis data dilakukan secara kualitatif dan kuantitatif. Untuk menjawab permasalahan faktor-faktor yang mempengaruhi investasi asing langsung di sektor perkebunan di Indonesia digunakan literature review. Berdasarkan literature review tersebut maka datadata sekunder yang dikumpulkan kemudian digunakan dalam analisis vector auto regreesion/vector error correction model. Untuk menjawab faktor-faktor strategis internal dan eksternal dan strategi yang dilakukan untuk meningkatkan investasi langsung sektor perkebunan di Indonesia dilakukan dengan menggunakan analisis SWOT untuk mengetahui apa saja yang menjadi kekuatan, kelemahan, peluang dan ancaman sedangkan untuk menentukan prioritas strategi dilakukan dengan AHP.

\section{Lokasi dan Waktu Penelitian}

Penelitian dilakukan di BKPM, KADIN, Dirjen Perkebunan, PT Wilmar International yang dilakukan selama tiga bulan dari bulan April sampai dengan Juni 2014. Responden dipilih secara sengaja (purposive sampling) dengan pertimbangan mewakili stakeholder sektor perkebunan.

\section{Data yang Diperlukan dan Sumbernya}

Penelitian ini menggunakan data primer dan data sekunder. Data primer diperoleh dari responden pakar di bidang perkebunan, dimana menggunakan kuesioner dan wawancara untuk memperoleh faktor internal dan eksternal. Data sekunder terkait variabel ekonomi diperoleh dari Deptan, BKPM, Bank Indonesia, BPS tahun dan berbagai rujukan lainnya dari tahun 1980 - 2012.

\section{Teknik Pengambilan Sampel}

Penarikan sampel yang dilakukan dalam penelitian ini menggunakan metode purposive sampling yaitu pemilihan responden dilakukan dengan sengaja, dimana peneliti menentukan sampel yang diambil dengan pertimbangan tertentu dengan harapan kriteria sampel memiliki pengetahuan, keahlian dan kompetensi dalam bidang yang diteliti yakni (1) Kepala Sub Direktorat Perencanaan Industri Agribisnis dan Sumber Daya Alam Badan Koordinasi Penanaman Modal; (2) Wakil - Wakil Ketua Umum Agribisnis dan Pangan; (3) Akademisi; (4) Kepala Sub Direktorat Tanaman Tahunan Direktorat Jenderal Perkebunan; 
(5) Manager Divisi Keuangan PT Wilmar International.

\section{Deskripsi Variabel dan Pengukuran}

$$
\begin{aligned}
& L F D I_{t}=\beta 01+\sum_{i=1}^{p} \beta_{i l} L F D I_{t-i}+\sum_{i=1}^{p} \alpha_{i 1} L_{E K S P O R_{t-i}+} \\
& \sum_{i=1}^{p} \lambda_{\perp} L E X R_{t-i}+\sum_{i=1}^{p} \gamma_{i l} L I H K_{t-i}+\sum_{i=1}^{p} \delta_{i l} L G D P_{t-i}+ \\
& \sum_{i=1}^{p} \phi_{i \perp} D_{I N T_{t-i}}+\sum_{i=1}^{p} \varpi_{i l} \text { FINT }_{t-i}+\text { DKrisis }+\varepsilon_{1 t} \ldots \ldots \ldots(1) \\
& \text { LFDI }_{\mathrm{t}} \quad=\text { Investasi asing langsung pada sektor }
\end{aligned}
$$

\begin{tabular}{|c|c|c|c|c|c|}
\hline \multirow[b]{2}{*}{ Variabel } & \multicolumn{2}{|c|}{ Koefisien } & \multirow[b]{2}{*}{ Kausalitas } & \multirow[b]{2}{*}{ IRF } & \multirow[b]{2}{*}{ VD } \\
\hline & $\begin{array}{l}\text { Jangka } \\
\text { Pendek }\end{array}$ & $\begin{array}{l}\text { Jangka } \\
\text { Panjang }\end{array}$ & & & \\
\hline $\begin{array}{l}\text { Investasi } \\
\text { Asing } \\
\text { Langsung }\end{array}$ & $0.404762^{*}$ & - & & $\begin{array}{c}\text { Respon } \\
\text { Positif }\end{array}$ & Dominan \\
\hline $\begin{array}{l}\text { Nilai } \\
\text { Tukar }\end{array}$ & $1.259127^{*}$ & - & $\begin{array}{l}\text { hubungan } \\
\text { satu arah }\end{array}$ & $\begin{array}{l}\text { Respon } \\
\text { Negatif }\end{array}$ & Dominan \\
\hline $\begin{array}{c}\text { Nilai } \\
\text { Ekspor }\end{array}$ & $2.065195^{*}$ & - & $\begin{array}{c}\text { hubungan } \\
\text { satu arah }\end{array}$ & $\begin{array}{c}\text { Respon } \\
\text { Positif }\end{array}$ & $\begin{array}{c}\text { Tidak } \\
\text { Dominan }\end{array}$ \\
\hline $\begin{array}{c}\text { Suku } \\
\text { Bunga AS }\end{array}$ & $0.532611^{*}$ & - & $\begin{array}{l}\text { hubungan } \\
\text { satu arah }\end{array}$ & $\begin{array}{l}\text { Respon } \\
\text { Negatif }\end{array}$ & $\begin{array}{c}\text { Tidak } \\
\text { Dominan }\end{array}$ \\
\hline $\begin{array}{c}\text { Suku } \\
\text { Bunga IND }\end{array}$ & 0.011569 & $0.291120^{*}$ & $\begin{array}{l}\text { Tidak ada } \\
\text { hubungan }\end{array}$ & $\begin{array}{l}\text { Respon } \\
\text { Negatif }\end{array}$ & $\begin{array}{c}\text { Tidak } \\
\text { Dominan }\end{array}$ \\
\hline $\begin{array}{c}\text { Produk } \\
\text { Domestik } \\
\text { Bruto }\end{array}$ & $9.847330^{*}$ & $1.952655^{*}$ & $\begin{array}{c}\text { hubungan } \\
\text { satu arah }\end{array}$ & $\begin{array}{c}\text { Respon } \\
\text { Positif }\end{array}$ & $\begin{array}{c}\text { Tidak } \\
\text { Dominan }\end{array}$ \\
\hline $\begin{array}{c}\text { Indeks } \\
\text { Harga } \\
\text { Konsumen }\end{array}$ & $1.347207^{*}$ & $0.191295^{*}$ & $\begin{array}{l}\text { Tidak ada } \\
\text { hubungan }\end{array}$ & $\begin{array}{c}\text { Respon } \\
\text { Positif }\end{array}$ & $\begin{array}{c}\text { Tidak } \\
\text { Dominan }\end{array}$ \\
\hline $\begin{array}{c}\text { Dummy } \\
\text { Krisis }\end{array}$ & $-4.670121^{*}$ & $-1.026009 *$ & $\begin{array}{c}\text { hubungan } \\
\text { satu arah }\end{array}$ & $\begin{array}{l}\text { Respon } \\
\text { Negatif }\end{array}$ & $\begin{array}{c}\text { Tidak } \\
\text { Dominan }\end{array}$ \\
\hline Konstanta & $1.117458^{*}$ & 4.231026 & & & \\
\hline
\end{tabular}

\section{Teknik Pengolahan dan Analisis Data}

Analisis yang dilakukan untuk data primer yakni (1) analisis deskriptif yang digunakan untuk mendeskripsikan investasi asing langsung dan variabel ekonomi di sektor perkebunan di Indonesia; (2) analisis evaluasi faktor eksternal dan internal; (3) perumusan alternatif strategi dengan menggunakan matriks SWOT; (4) penentuan prioritas strategi yang telah dirumuskan berdasarkan pembobotan AHP. Sedangkan untuk analisis data sekunder yakni (1) Analisis VAR/VECM; (2) Analisis Uji Kausalitas Granger; (3) Variance Decomposition; (4) Impulse Response Factor.

\section{HASIL DAN PEMBAHASAN}

Hasil Estimasi Vector Error Correction Model Hasil estimasi VECM penelitian ini diketahui hubungan jangka pendek dan jangka panjang dari variabel makroekonomi yang digunakan dalam penelitian terhadap variabel FDI.

Tabel 1 Hasil Uji VECM

Sumber: Hasil Olahan

\section{Investasi Asing Langsung dan Ekspor}

Hasil estimasi menunjukan bahwa dalam jangka pendek kenaikan nilai ekspor sebesar satu persen akan meningkatkan investasi asing langsung sebesar 2.06 persen. Hal ini menunjukan terdapat hubungan positif antara nilai ekspor terhadap investasi asing langsung. Hubungan investasi asing langsung terhadap eskpor bersifat uni-directional atau hubungan satu arah yang menunjukan bahwa ekspor menyebakan investasi asing langsung, namun investasi asing langsung tidak menyebabkan ekspor. Hal ini terjadi karena sektor perkebunan dominan melakukan ekspor sehingga menarik investor (multinational company) dalam menanamkan modalnya. Motivasi investor dalam melakukan investasi asing langsung pada sektor perkebunan di Indonesia adalah untuk pasar ekspor. Investasi yang didasari hal alasan ini merupakan investasi vertikal. Investasi ini ditujukan untuk memperbesar keuntungan komparatif seperti meningkatkan akses terhadap bahan mentah yang 


\section{JURNAL BISNIS \& MANAJEMEN}

ISSN 1412 - 3681

dilakukan perusahaan investor untuk mengatasi kendala perdagangan dalam melayani pasar asing (foreign market). Dalam jangka panjang, guncangan nilai ekspor direspon positif oleh investasi asing langsung. Hal ini menjelaskan bahwa peningkatan ekspor akan meningkatkan investasi asing langsung pada sektor perkebunan.

\section{Investasi Asing Langsung dan Nilai Tukar}

Hasil estimasi dalam jangka pendek menunjukan apabila nilai tukar rupiah terdepresiasi sebesar satu persen akan meningkatkan investasi asing lansung sebesar 1.26 persen atau jika rupiah terapresiasi sebesar satu persen akan menurunkan investasi asing langsung sebesar 1.26 persen. Dalam jangka panjang, guncangan nilai tukar direspon negatif oleh investasi asing langsung. Hal ini menjelaskan bahwa depresiasi nilai tukar akan menurunkan investasi asing langsung pada sektor perkebunan.

Target investor dalam melakukan investasi asing langsung di sektor perkebunan yakni untuk pasar ekspor, dimana mekanisme penjualan ekspor berdasarkan hard currency, sedangkan struktur biaya produksi menggunakan mata uang domestik yakni rupiah atau dengan kata lain apabila rupiah terdepresiasi maka harga jual akan meningkat sementara biaya produksi relatif tetap, dengan demikian investor akan memperoleh keuntungan dari terdepresiasinya mata uang domestik rupiah. Sebagai contoh, pada industri pembibitan perkebunan bahan baku diperoleh melalui impor, sehingga hal ini berdampak pada peningkatan biaya investasi tanaman baru.

Kestabilan nilai tukar merupakan salah satu faktor yang mempengaruhi masuknya investasi di dalam negeri. Oleh karena itu otoritas moneter harus menjaga stabilitas nilai tukar di Indonesia melalui kebijakan moneter jangka panjang serta jangka pendek (Indro, 2003).

\section{Investasi Asing Langsung dan Suku Bunga Luar Negeri - AS}

Hasil estimasi dalam jangka pendek menunjukan apabila suku bunga AS mengalami peningkatan sebesar satu persen akan meningkatkan investasi asing langsung sektor perkebunan di Indonesia sebesar 0.53 persen, sebaliknya apabila suku bunga
Jurnal Bisnis \& Manajemen, 2015, Vol. XVI, No. 2, 80-89

AS mengalami penurunan sebesar satu persen akan menurunkan investasi asing langsung sektor perkebunan di Indonesia sebesar 0.53 persen. Tingkat suku bunga bukan merupakan variabel yang signifikan di dalam mempengaruhi investasi yang masuk ke dalam suatu negara. Hal ini disebabkan investasi asing langsung merupakan investasi yang dilakukan di dalam jangka panjang baik dalam bentuk merger maupun akuisisi, sehingga perbedaan tingkat suku bunga yang terjadi di dalam waktu yang singkat tidak akan membuat investor untuk segara menurunkan atau menambah jumlah investasinya (Afrizawati, 2011). Hal ini bertentangan dengan Pardamean et al (2008) yang menjelaskan bahwa suku bunga yang tinggi akan mendorong investor untuk menanamkan dananya di bank daripada menginvestasikannya pada sektor produksi atau industri yang memiliki tingkat risiko lebih besar. Namun dalam jangka panjang, guncangan suku bunga luar negeri direspon negatif oleh investasi asing langsung. Hal ini menjelaskan bahwa peningkatan suku bunga luar negeri akan menurunkan investasi asing langsung pada sektor perkebunan. Motivasi investor dalam melakukan investasi asing langsung pada sektor perkebunan di Indonesia adalah untuk melayani pasar asing (foreign market) bukan market seeking.

\section{Investasi Asing Langsung dan Suku Bunga Dalam Negeri - IND}

Analisis jangka pendek menunjukan bahwa suku bunga dalam negeri tidak berpengaruh secara parsial terhadap investasi asing langsung. Namun suku bunga dalam negeri pada analisis jangka panjang berpengaruh signifikan terhadap investasi asing langsung, dimana kenaikan sebesar satu persen pada suku bunga dalam negeri akan meningkatkan investasi asing langsung sebesar 0.29 persen.

Hal ini terjadi karena tingkat pengembalian modal yang dapat dinikmati oleh investor asing masih lebih besar dibandingkan dengan tingkat suku bunga yang harus dibayarkan oleh investor kepada bank. Dengan suku bunga kredit investasi 15 persen perkebunan besar memperoleh keuntungan bersih Rp 1.957.000/ha/tahun dari hasil penjualan tandan buah segar bila harga minyak sawit Rp 8.000/kg dan inti sawit Rp 5.500/kg (Herman, 2009) dan Investor asing tidak menggunakan pembiayaan modal dari negara host countries (Yutaka, 2012). Namun otoritas 
moneter harus mengantisipasi terkait kebijakan dalam meningkatkan suku bunga karena adanya peningkatan atau guncangan suku bunga dalam negeri akan menurunkan investasi asing langsung pada sektor perkebunan.

Investasi Asing Langsung dan Produk Domestik Bruto Analisis jangka pendek menunjukan apabila produk domestik bruto mengalami peningkatan sebesar satu persen akan meningkatkan investasi asing langsung sektor perkebunan di Indonesia sebesar 9.84 persen. Sedangkan analisis jangka panjang menunjukan apabila produk domestik bruto meningkat sebesar satu persen maka investasi asing langsung sektor perkebunan di Indonesia meningkat sebesar 1.95 persen.

Produk domestik bruto merepresentasikan ukuran pasar pada suatu negara serta sebagai pull factor bagi para investor asing. Dalam penelitian ini produk domestik bruto memiliki nilai koefisien positif tertinggi yang berpengaruh signifikan terhadap investasi asing langsung, dengan demikian pemerintah harus meningkatkan laju pertumbuhan ekonomi di Indonesia. Kenaikan pertumbuhan ekonomi suatu negara mengindikasikan adanya pertambahan besarnya pasar (market size). Negara dengan kondisi seperti ini merupakan tujuan investasi yang menarik para investor asing.

\section{Investasi Asing Langsung dan Indeks Harga Konsumen} Indeks harga konsumen berpengaruh positif terhadap investasi asing langsung baik pada jangka pendek maupun jangka panjang. Analisis jangka pendek menunjukan apabila indeks harga konsumen mengalami peningkatan sebesar satu persen maka investasi asing langsung sektor perkebunan di Indonesia akan meningkat sebesar 1.34 persen. Analisis jangka panjang menunjukan bahwa peningkatan indeks harga konsumen sebesar satu persen maka investasi asing langsung akan meningkat sebesar 0.19 persen.

Indeks harga konsumen merupakan representasi dari inflasi yang mencerminkan kekuatan daya beli masyarakat, semakin tinggi tingkat inflasi maka daya beli masyarakat semakin rendah. Dalam kondisi daya beli masyarakat yang rendah, maka pilihan yang lebih menguntungkan adalah tidak melakukan investasi. Di Indonesia jika ditelusuri lebih jauh, inflasi lebih disebabkan oleh adanya hambatan di sisi pasokan dan persoalan struktural pada jalur distribusi, bukan disebabkan oleh permintaan (Indro, 2003), namun penurunan inflasi mempengaruhi daya beli masyarakat, sehingga para investor asing yang memiliki motif market seeking tertarik untuk berinvestasi di Indonesia (Suwarno, 2008).

\section{Investasi Asing Langsung dan Krisis}

Dummy krisis berpengaruh terhadap investasi asing langsung baik pada jangka pendek maupun jangka panjang. Analisis jangka pendek menunjukan apabila terjadi krisis maka investasi asing langsung sektor perkebunan akan turun sebesar 4.67 persen, sebaliknya apabila tidak terjadi krisis maka investasi asing langsung tidak mengalami peningkatan, sedangkan pada jangka panjang apabila terjadi krisis akan menyebabkan penurunan investasi asing langsung sebesar 1.02 persen.

\section{Perumusan Strategi pada Sektor Perkebunan di Indonesia}

Hasil wawancara dan kuisioner dengan responden pakar menghasilkan bobot dan faktor faktor eksternal dan internal yang berhubungan dengan sektor perkebunan di Indonesia pada tabel di bawah ini.

Tabel 2 Matriks Evaluasi Faktor Internal

\begin{tabular}{|c|c|c|}
\hline No & Faktor & Bobot \\
\hline \multicolumn{3}{|c|}{ Kekuatan } \\
\hline 1 & Kontribusi ketiga terbesar terhadap PDB & 0.071 \\
\hline 2 & $\begin{array}{l}\text { Penghasil utama minyak kelapa sawit dunia, penghasil karet } \\
\text { kedua terbesar dunia, serta penghasil kakao dan kopi ketiga } \\
\text { terbesar dunia. }\end{array}$ & 0.203 \\
\hline 3 & $\begin{array}{l}\text { Bisnis perkebunan mempunyai daya tahan tinggi karena } \\
\text { berbasis pada sumberdaya domestik dan berorientasi ekspor }\end{array}$ & 0.110 \\
\hline 4 & $\begin{array}{l}\text { Ketersediaan tenaga kerja dimana sektor perkebunan intensif } \\
\text { menggunakan tenaga kerja, khususnya tenaga kerja yang } \\
\text { berlokasi di pedesaan }\end{array}$ & 0.077 \\
\hline 5 & $\begin{array}{l}\text { Potensi Luas Areal belum berproduksi dan pertambahan } \\
\text { areal berproduksi }\end{array}$ & 0.539 \\
\hline \multicolumn{3}{|c|}{ Kelemahahan } \\
\hline 1 & Konflik dan Persengketaan Lahan & 0.421 \\
\hline 2 & Kondisi Iklim & 0.049 \\
\hline 3 & Investasi yang relatif besar di sektor Perkebunan & 0.080 \\
\hline 4 & Rendahnya produktivitas dan kualitas produksinya & 0.083 \\
\hline 5 & $\begin{array}{l}\text { Rendahnya Inovasi dan perkembangan penelitian nasional } \\
\text { Sektor Perkebunan }\end{array}$ & 0.080 \\
\hline 6 & Industri hilir sektor perkebunan yang belum optimal & 0.198 \\
\hline
\end{tabular}

Sumber: Data diolah 
Lanjutan Tabel 2 Matriks Evaluasi Faktor Internal

\begin{tabular}{clc}
\hline No & \multicolumn{1}{c}{ Kaktor } & Kolemahan \\
\hline & & \multicolumn{1}{c}{ Bobot } \\
7 & Harga komoditas perkebunan berfluktuasi cukup tajam & 0.031 \\
8 & Kurang dalam memperhatikan kesejahteraan buruh & 0.028 \\
9 & $\begin{array}{l}\text { Rendahnya perusahaan perkebunan yang telah diseertifikasi } \\
\text { terhadap produk perkebunan }\end{array}$ & 0.028 \\
\hline
\end{tabular}

Sumber: Data diolah

Pada saat ini luas perkebunan kelapa sawit - baik yang telah berproduksi maupun land bank perusahaan adalah seluas 11 juta hektar dan di tahun 2020 alokasi untuk perkebunan kelapa sawit mencapai 28 juta hektar. Luas areal sektor perkebunan tahun 2008 sebesar 19.3 juta hektar menjadi 21.6 juta ha pada tahun 2013 atau meningkat sebesar $12 \%$ per tahun. Hal ini menunjukan bahwa peningkatan kapasitas dan hasil produksi sektor perkebunan menunjukan kecenderungan yang positif dalam beberapa tahun terakhir.

Persengketaan atau konflik lahan perkebunan adalah permasalahan lain yang sangat mengganggu bisnis perkebunan. Akhir-akhir ini, konflik penguasaan lahan semakin merebak antara perusahaan perkebunan dan masyarakat, perusahaan - pemerintah (Kementerian Kehutanan, pemerintah daerah), maupun antarsesama pengusaha. Data pada awal 2013 di Ditjen Perkebunan Kementerian Pertanian menunjukkan jumlah gangguan atau konflik di perusahaan perkebunan mencapai 541 kasus dan $74 \%$ di antaranya terkait konflik penguasaan lahan. Dari jumlah tersebut, konflik yang sudah diselesaikan baru $10 \%$.

\section{Tabel 3 Matriks Evaluasi Faktor Eksternal}

\begin{tabular}{|c|c|c|}
\hline No & Faktor & Bobot \\
\hline \multicolumn{3}{|c|}{ Peluang } \\
\hline 1 & Proyeksi Peningkatan Perekonomian Global & 0.455 \\
\hline 2 & $\begin{array}{l}\text { Indonesia menempati posisi keempat negara tujuan investasi } \\
\text { paling prospektif dan termasuk negara investment grade }\end{array}$ & 0.088 \\
\hline 3 & $\begin{array}{l}\text { Bonus Demografi, sesuai dengan kebijakan mendorong } \\
\text { industri sektor hilir sehingga terjadi peningkatan konsumsi } \\
\text { domestik yang dimulai pada } 2015 \text { - } 2020\end{array}$ & 0.075 \\
\hline 4 & Peningkatan Indeks Daya Saing Indonesia & 0.076 \\
\hline 5 & $\begin{array}{l}\text { Peraturan Presiden Nomor } 39 \text { Tahun } 2014 \text { tentang.daftar } \\
\text { bidang usaha yang tertutup dan bidang usaha yang terbuka } \\
\text { dengan persyaratan di bidang penanaman modal }\end{array}$ & 0.078 \\
\hline 6 & Kebijakan Internasional terkait penggunaan biodiesel & 0.189 \\
\hline
\end{tabular}

Lanjutan Tabel 3 Matriks Evaluasi Faktor Eksternal

\begin{tabular}{|c|c|c|}
\hline No & Faktor & Bobot \\
\hline \multicolumn{3}{|c|}{ Peluang } \\
\hline 7 & $\begin{array}{l}\text { Implementasi PMK No67/PMK.011/2010 untuk mendorong } \\
\text { hilirisasi di sektor perkebunan seperti kelapa sawit dan } \\
\text { kakao }\end{array}$ & 0.039 \\
\hline \multicolumn{3}{|c|}{ Ancaman } \\
\hline 1 & $\begin{array}{l}\text { Pertumbuhan Ekonomi Indonesia relatif turun selama tiga } \\
\text { tahun terakhir }\end{array}$ & 0.039 \\
\hline 2 & $\begin{array}{l}\text { Penurunan indeks memulai bisnis yang pada tahun } 2013 \text { ada } \\
\text { di peringkat } 116 \text { menjadi peringkat } 120 \text { pada tahun } 2014\end{array}$ & 0.039 \\
\hline 3 & $\begin{array}{l}\text { Kualitas infrastruktur yang relatif rendah jika dibandingkan } \\
\text { dengan negara Malaysia, Singapura dan Thailand }\end{array}$ & 0.079 \\
\hline 4 & $\begin{array}{l}\text { Ketidaksinergisan antara kebijakan yang dikeluarkan } \\
\text { pemerintah pusat dengan pemerintah daerah kebijakan } \\
\text { terkait perijinan dan juga tata ruang dan wilayah }\end{array}$ & 0.328 \\
\hline 5 & $\begin{array}{l}\text { Peraturan Menteri Pertanian (Permentan) No 98/2013 } \\
\text { tentang izin usaha perkebunan }\end{array}$ & 0.205 \\
\hline 6 & $\begin{array}{l}\text { Kampanye Negatif terkait permasalahan Pemanasan Global } \\
\text { dan Perubahan Iklim }\end{array}$ & 0.143 \\
\hline 7 & $\begin{array}{l}\text { Persaingan Bisnis akibat adanya kehadiran pesaing negara } \\
\text { lain dalam meningkatkan Investasi Asing Sektor Perkebunan }\end{array}$ & 0.111 \\
\hline 8 & Tekanan Politik & 0.056 \\
\hline
\end{tabular}

Proyeksi sebagian besar negara kawasan tujuan utama ekspor Indonesia diperkirakan berada dalam trend pertumbuhan. Hal ini akan berdampak pada peningkatan volume dan harga jual ekspor komoditas perkebunan (Sawit, Karet dan Kakao).

Terbitnya UU No 22 Tahun 1999 tentang Pemerintah Daerah, yang kemudian direvisi dengan UU No 32 Tahun 2004, juga berdampak sangat signifikan terhadap jalannya bisnis perkebunan. Pemerintah daerah (kabupaten) memiliki kewenangan yang lebih besar dalam berbagai sektor, termasuk subsektor perkebunan. Kewajiban menggali sumber pendapatan bagi pemda dalam rangka mendongkrak pendapatan asli daerah (PAD), sering berimbas pada peningkatan biaya operasi usaha perkebunan. peraturan Menteri Pertanian No.98/2013 tentang izin usaha perkebunan merupakan subfaktor yang memiliki bobot tertinggi kedua sebesar 0.205. Regulasi ini terkait adanya pembatasan luas maksimal lahan perkebunan yang dimiliki oleh satu grup usaha. Sebagai contoh, satu kelompok usaha hanya boleh memiliki kebun sawit maksimal 100.000 hektar. Jika lebih, pengusaha wajib melepas sebagian sampai memenuhi batas maksimal. maksimal hanya boleh membuka lahan tanaman sawit 100.000 hektar (ha), tebu 150 ribu ha, dan teh 20 ribu ha. Sedangkan luas maksimal untuk tanaman 
kelapa 40 ribu ha, karet 20 ribu ha, kapas 20 ribu ha, kopi 10 ribu ha, kakao 10 ribu ha, jambu mete 10 ribu ha, lada 1.000 ha, dan cengkih 1.000 ha.

Tabel 4 Matriks Evaluasi Faktor Eksternal

\begin{tabular}{cl}
\hline No & \multicolumn{1}{c}{ Faktor } \\
\hline 1 & \multicolumn{1}{c}{ Strategi So } \\
& $\begin{array}{l}\text { Reformulasi pasar dalam negeri dan luar negeri } \\
\text { pengadaan sarana produksi, proses produksi usaha tani, } \\
\text { pengolahan hasil, dan pemasaran produk serta subsistem } \\
\text { penunjangnya }\end{array}$ \\
& $\begin{array}{l}\text { Meningkatkan promotional mix (periklanan, sales promotion, } \\
\text { public relation/marketing communication dan personal } \\
\text { selling) sektor perkebunan yang merupakan bagian dari } \\
\text { strategi promosi investasi }\end{array}$
\end{tabular}

Bobot

\section{Strategi Wo}

1 Mengoptimalkan Inovasi Teknologi Sektor Perkebunan

0.027

Mengoptimalkan faktor pendukung berupa rekayasa sosial,

2 kelembagaan, ekonomi, dan lingkungan yang sering menjadi sumber permasalahan operasional usaha perkebunan

3 Mengintensifkan program hilirisasi di sektor perkebunan

Skema standarisasi dan sertifikasi sendiri atas produk sektor

4 perkebunan, contoh : kelapa sawit yang dikenal dengan ISPO (Indonesia Sustainable Palm Oil)

\section{Strategi ST}

1 Adanya kepastian hukum untuk mendorong iklim usaha yang kondusif

2 Harmonisasi peraturan perundang-undangan

Percepatan proses legalitas perizinan dan perpanjangan HGU) oleh pemerintah

4 Perbaikan Infrastruktur

Strategi WT

membentuk forum kerja sama yang lebih intensif antara pelaku bisnis perkebunan, peneliti, pemerintah, dan

1 masyarakat perlu dibangkitkan guna menciptakan iklim usaha perkebunan yang lebih baik dan menjamin keberlanjutan pembangunan perkebunan

Penegakan hukum bagi para pelaku pelanggaran, pencurian

2 dan penjarahan, serta gangguan terhadap usaha operasional kebun

Sumber: Data diolah

\section{Implikasi Manajerial}

Masuknya investor asing dalam kegiatan investasi di Indonesia dimaksudkan untuk mengisi sektor usaha dan industri yang belum dapat dilaksanakan sepenuhnya oleh pemerintah, BUMN dan swasta nasional yang disebabkan permodalan, manajemen maupun teknologi yang selanjutnya investasi asing tersebut diharapkan secara langsung dapat mempercepat proses pembangunan ekonomi Indonesia. Berdasarkan hal tersebut maka implikasi manajerial pada penelitian ini adalah :
Pertama bagi Pemerintah dengan cara (1) meningkatkan pertumbuhan ekonomi dan stabilitas perekonomian; (2) regulasi yang sinkron dan konsisten dalam mendukung investasi; (3) penanganan konflik; 4) mendorong para investor untuk meningkatkan nilai tambah sektor perkebunan melalui pengembangan industri hilir.

Kedua bagi Investor dengan cara (1) Menilai perekonomian host countries; (2) Mengelola bisnis perkebunan berdasarkan best management practices; (3) Mereduksi konflik; (4) melakukan penilaian atas kepastian hukum serta regulasi yang mendukung investasi sektor perkebunan.

\section{KESIMPULAN}

Pertama faktor faktor yang berpengaruh terhadap investasi asing langsung pada sektor perkebunan di Indonesia ditinjau dari variabel ekonomi yakni (a) Dalam jangka pendek, variabel nilai tukar, nilai ekspor, suku bunga Amerika Serikat, produk domestik bruto dan indeks harga konsumen berpengaruh positif terhadap investasi asing langsung pada sektor perkebunan di Indonesia. Sementara krisis berpengaruh negatif terhadap investasi asing langsung pada sektor perkebunan di Indonesia. (b) Dalam jangka panjang, variabel suku bunga dalam negeri, produk domestik bruto dan indeks harga konsumen berpengaruh positif, sementara krisis berpengaruh negatif terhadap investasi asing langsung pada sektor perkebunan di Indonesia.

Kedua faktor faktor yang berpengaruh terhadap investasi asing langsung pada sektor perkebunan di Indonesia ditinjau dari lingkungan internal dan eksternal sektor perkebunan yakni areal sektor perkebunan yang merupakan input produksi, konflik atau persengketaan lahan, proyeksi peningkatan ekonomi dunia dan kebijakan pemerintah pusat dan daerah yang tidak sinergis.

Ketiga prioritas strategi untuk meningkatkan investasi asing langsung pada sektor perkebunan di Indonesia yakni dengan melakukan harmonisasi perundang undangan baik pemerintah pusat maupun daerah.

\section{Saran}

Saran untuk penelitian lebih lanjut terhadap faktor 


\section{JURNAL BISNIS \& MANAJEMEN}

ISSN 1412 - 3681

yang mempenharuhi investasi asing langsung sektor perkebunan di Indonesia dan strategi untuk meningkatkan investasi asing langsung yakni :

Pertama menggunakan variabel rate of return untuk mengetahui tingkat keuntungan dalam berinvestasi pada sektor perkebunan di Indonesia.

Kedua menggunakan variabel ekonomi setiap propinsi untuk menghasilkan penelitian terkait lokasi yang strategis untuk berinvestasi serta melakukan analisis faktor dalam menentukan faktor-faktor yang berpengaruh terhadap investasi asing di Indonesia.

Ketiga menambah responden pakar antara lain otoritas pertanahan, kementerian kehutanan, aparatur keamanan, kepala daerah atau kepala dinas daerah untuk mendapatkan karakterisitk lingkungan eksternal dan internal, sehingga penelitian lebih komprehensif.

\section{DAFTAR PUSTAKA}

Antoni (2008). Investasi Asing Langsung dan Perdagangan di Indonesia. Jurnal Ekonomi Bisnis dan Koperasi Vol.10 No.2, Oktober 2008.

Caves (1982). International Corporations : The Industrial Economics of Foreign Investment.

Hari (2004). Strategi Pengembangan Sub Sektor Kehutanan dan Perkebunan di Kabupaten Rembang. Tesis Fakultas Ekonomi Undip. 2004.

Herman (2009). Analisis Finansial dan Keuntungan yang Hilang dari Pengurangan Emisi Karbondioksida pada Perkebunan Kelapa Sawit . Jurnal Litbang Pertanian 28(4) 2009.

John (2013). Analisis Pengaruh PDB, Inflasi, Suku
Jurnal Bisnis \& Manajemen, 2015, Vol. XVI, No. 2, 80-89

Bunga dan Krisis Moneter terhadap FDI Indonesia. Tesis Fakultas Ekonomi Undip. 2013

Masuku, M. B., \& Dlamini, T. S. (2009). Determinant of Foreign Direct Investment and Volatility in ASIAN Economics. 1(5), 177-184.

M. Alhasymi (2011). Analisis Kausalitas dan Kointegrasi antara FDI dengan GDP di Australia. MEPA Ekonomi, Vol-1 No-1.

M. Kholis (2012). Dampak Foreign Direct Investment terhadap Pertumbuhan Ekonomi Indonesia. Jurnal Organisasi dan Manajemen, Volume 8, Nomor 2, September 2012, 111-120.

M. Rasyidin (2011). Pengaruh Foreign Direct Investment terhadap Pengembangan Pasar Saham di Indonesia. JEJAK, Volume 1, Nomor 3, 2011.

Nathaporpan (2005). Foreign Direct Investment in ASEAN countries. Journal of Laboratoire $d^{\prime}$ économie de Nantes (LEN).JEL Classification F23.

Pardamean, Sya'ad, \& Kasyful (2008). Analisis Faktor Faktor yang Mempengaruhi Permintaan Investasi di Indonesia. MEPA Ekonomi, Vol-3 No-2.

Piyaphan (2010). The Determinants of FDI Inflows by Industry to ASEAN. A dissertation submitted to the faculty of The University of Utah, 2010.

Rabin, Ramkishen, \& Shandre (2008). Understanding Intra ASEAN FDI Flows. Trends and Determinants and the Role of China and India. Journal of World Bank and George Mason University. 